\title{
International Seminar on Dust Collection
}

\author{
（集じんに関する国際セミナー）
}

1977年 5 月に東京で開催されて国際清浄空気会議に際 して，多数の有名な海外の研究者が来日された機会をと ら壳, 標記のセミナーが5月24日午後, 京都国際会議場 で開かれた。日本粉体工業協会・集塺分科会, 粉体工学 研究会・エアロゾルグループ会の主催で, 乖伊谷先生が オーガナイズされたものである。

このセミナーで行なわれた講演と講演者は下記の通り であるが, このほかにもアメリカの R.W. McIlvaine 氏, R. H. Horning 氏，オーストラリアの K. M. Sullivon 氏，J.W. Baker 氏らが出席され，また日本側から る分科会・グループ会の主要メンバーが㤬とんど出席 し，きわめて国際色に富んだ会議となった。

たとえばドイッの Löffler 教授とアメリカの First 教 授が，フィルタ一面上に捕集された粉体層に就ける王損 をめぐってなかなかきびしくやりあわれたり，日本側か らあ Potter 氏の電気集じん機の新しい考方方や， Stöber 教授の測定法に関する新しいアイディアに対して盛 んな翼問がでたり，あるいはバグからの払い落しに関し て日本のメ一カーの方からの意見がでたり，きわめて活 ぱつで有意義な国際的会議であった。これはオーガナイ ザーの井伊谷先生, 討論司会の増田閃一先生のとさには 通訳もか水た名りードぶりに負うところが大きかった が，こらいら肩のこらない気軽るな会で，フリーに外国 人と議論をする，といらことが，われわれにも段々なじ

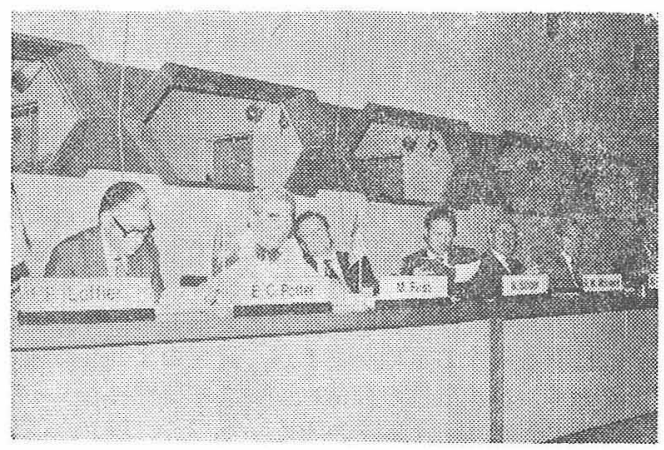

んできたことのあらわれかとも思われた。会議後ひきつ つきき京都国際会議場の緑を空外にみながら愁親会が開か れたがこれもきわめてなごやかな中話しがはずみ， 国際交流の美があげられたのであった。

このような informal な国際交流は, とりわけ若い研 究者の人々にとっていい刺激になると思われ，機会があ ればもっと盛んにやっていただきたいものである。

(神保元二記)

\section{講演テーマ}

1.あいさつ

京都大学 井伊谷鋼一教授

2. 粒子・ガス分離に执ける研究の概念

ドイッカールスルーエ大学 F. Löffler 教授

3. 電気集䵇技術における新しいアイディア

オーストラリア CSIRO E.C. Potter 部長

4. ハーバード大学空気清浄研究室に拈ける集歴関す る鼠近の研究

アメリカ ハーバード大学 M. First 教授

5. 遠心分離機によるエーロゾルの粒度別捕集

$$
\begin{aligned}
& \text { ドイッミミンスター大学 } \\
& \text { エーロバイオロジー研究所長 W.Stöber 教授 }
\end{aligned}
$$

6. 討論司会 東大 增田閃一教授 阪府大 吉田哲夫教授

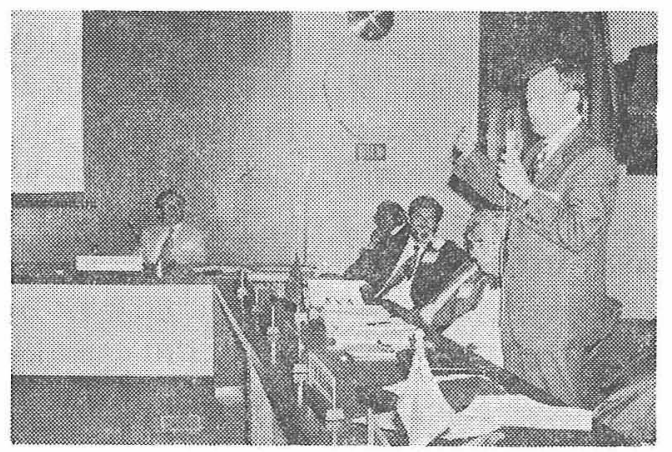

